\title{
Interdiskurzivita spomínania v literárnom diele Christy Wolf
}

\section{NADEŽDA ZEMANÍKOVÁ}

DOI: https://doi.org/10.31577/WLS.2021.13.4.4

Kritické reflektovanie oficiálnych historiografických obrazov a oficiálnych naratívov minulosti $\mathrm{v}$ dôsledku zániku totalitných režimov spojené s odkrývaním zabudnutého a vytesneného, ako aj odchádzanie priamych svedkov hrôz 20. storočia viedlo na jeho konci k markantnej „konjunktúre pamäti“ ${ }^{\text {“1 }}$ (Nora 2002, 18). Vedecké výskumy pamäti integrujúce poznatky viacerých špeciálnych diskurzov prírodných aj humanitných vied nadobudli výrazne interdisciplinárny charakter (Schmidt 1991), ich poznanie sa však komunikuje $\mathrm{v}$ širších kontextoch naprieč systémami prostredníctvom reintegrujúcich interdiskurzov, ku ktorým patrí aj literatúra (Link 1988; 2013). Pri analýze špecifického spôsobu, akým významná nemecká autorka Christa Wolf vo svojom diele literarizuje poznatky vedeckých výskumov pamäti, sa budeme opierat o koncepciu pamäti v humanitných a spoločenských vedách zdôrazňujúcu kultúrnu, sociálnu a komunikatívnu dimenziu pamäti², nie jej biologické parametre.

Známe teórie kultúrnej pamäti z dielne Aleidy a Jana Assmannovcov, kriticky nadväzujúce na výskumy francúzskeho sociológa Maurica Halbwachsa a historika umenia Abyho Warburga, pritom do velkej miery pracujú s metaforikou pamäti blízkou metaforizácii spomínania v literárnej komunikácii. Aleida Assmann (1999, 149 178) pri metaforike spomínania rozlišuje metafory písma (tabula, kniha, palimpsest), priestorové metafory (chrám, knižnica, vykopávky) a časové metafory pamäti (prehĺtanie, prežúvanie, trávenie; zmrazovanie a rozmrazovanie; spánok a prebudenie; privolávanie duchov), pričom metaforiku pamäti vníma ako neoddelitelne spojenú s medialitou pamäti. Písmo tak nie je iba po stáročia prítomným základným médiom pamäti, ale aj dôležitou metaforou pamäti a od nástupu moderny aj symbolom zlyhania pamätových procesov. Viaceré metafory sa viažu tiež na pamät tela.

Christa Wolf (1929 - 2011) je autorkou, pre ktorej tvorbu má spomínanie existenčný význam. Už vo svojom zásadnom poetologickom texte Lesen und Schreiben (Č́́tanie a písanie) z roku 1968 si uvedomovala nemožnost̉ objektívneho stvárnenia minulosti a rozhodla sa „rozprávat, to znamená: pravdivo vymýšlat na základe vlastnej skúsenosti“" ${ }^{\text {“3 }}$ (Wolf 1986, 25). Autorka za svoje písanie preberá etickú zodpovednost' a vstupuje do dialógu s recipientom. V súlade s nemeckým „Nach-Denken“ vníma spomínajúce premýšlanie ako návraty v myšlienkach, ktoré spolu so sebaskúmaním a sebapoznávaním tvoria $\mathrm{v}$ autorkinej tvorbe jadro subjektívnej autentickosti, jej poetologického programu. $V$ ňom metaforizuje spomínanie ako plávanie proti prúdu: 
„Spomínat si je plávat proti prúdu, ako písat - proti zdanlivo prirodzenému prúdu zabúdania, namáhavý pohyb ${ }^{\text {“4 }}(24)$. Autorkine klúčové sebareflexívne texty, román Kindheitsmuster (1976; Model detstva, 1980) ${ }^{5}$ i posledné autobiografické dielo Stadt der Engel oder The Overcoat of Dr. Freud (Mesto anjelov alebo Zvrchník Dr. Freuda, 2010), inscenujú proces písania, v ktorom sa sebaspytovanie prelína s reflexiami procesu spomínania a literarizáciou pamäti. Tvorba Christy Wolf velmi presne reflektuje životné peripetie generácie narodenej v medzivojnovom období, $\mathrm{v}$ detstve formovanej nacistickým režimom, na konci vojny skúsenostou úteku z rodného mesta, skúsenostným zlomom po porážke Nemecka, ktorý v budovatelskej generácii vzbudil nadšenie pre komunistickú utópiu, a nakoniec konfliktmi v reálnom socializme NDR i skúsenostou jeho pádu.

Žiadnej inej životnej etape sa Christa Wolf vo svojej tvorbe nevenovala väčšmi ako svojmu detstvu v nacistickom Nemecku. Od konca 60. rokov Wolf už ako etablovaná autorka NDR neprestajne hladá podobu literárneho stvárnenia svojej socializácie v Tretej ríši, ktorým chce preniknút k základom svojho neskoršieho zmýšlania a konania ovplyvneného „vzormi detstva“. Už v denníkovom texte z 27. septembra 1967 sa zmieňuje o úmysle začat s s,knihou o štyridsiatom piatom“ $(2003,102)$. Aj neskoršie denníkové záznamy dokladajú neustály zápas autorky o poetické uchopenie formatívnych súčastí autobiografickej pamäti.

V roku 1970 vznikla próza Blickwechsel (Zmena pohladu, 1989), jeden z prvých pokusov zachytit spomienky na nútený útek z rodného mesta ako radikálny životný zlom. O rok neskôr napísala Christa Wolf v netypicky krátkom čase prozaický text Nachruf auf Lebende. Die Flucht (Nekrológ za živými. Útek, 2014), ktorý sa stal predchodcom diela Model detstva. ${ }^{6}$ „Nie, tak to nebolo“7 (9), úvodná veta textu môže evokovat nesúlad individuálnych spomienok a oficiálneho spomínania na útek a udalosti, ktoré mu predchádzali. Už tieto prvé podoby literárneho spomínania sa pokúšajú rekonštruovat’ vznik bielych miest vo vztahu k taživej minulosti. Pracujú s naratívnymi stratégiami, ktoré Model detstva rozvinie vo vel'kom formáte, a tým priamo ovplyvní aj literárnoteoretický diskurz o autobiografickom písaní.

\section{MODEL DETSTVA}

Román Model detstva sa začína notoricky známym citátom Williama Faulknera: „Minulé nie je mŕtve, ani len nepominulo“8 $(1976,9)$. Rozprávanie vedie vedomá snaha rozprávačky oddelit od seba minulost’ a postupne sa priblížit svojmu minulému ja vo viacvrstvovom introspektívnom naratívnom procese. Úvodné tvrdenie, že sa v minulosti spomínalo lahšie, odhaluje rozprávačka ako svoj další pokus zabarikádovat’ sa. Metafory zakuklenia, zátarás a barikád, z ktorých sa nedá vyslobodit, nás sprevádzajú aj v dalších autorkiných dielach. Nespolahlivá pamät je selektívna a „jej úloha znie: Zabudnút! Falšovat!"“9 (14) V súlade s aktuálnym poznaním vo výskumoch pamäti nevníma rozprávačka pamät ako orgán, „ale [ako] činnost’ a predpoklad na jej vykonávanie v jednom slove ${ }^{10}$ (18). Pre seba však vidí iba možnost’ volby medzi zotrvaním v nemote a životom $v$ tretej osobe. Na scénu teda prichádza trojročné dieta s fiktívnym menom Nelly a mlčanie sa mení, ako píše, na „krížový výsluch teba samej ${ }^{“ 11}(9)$. Christa Wolf vytvára v diele viaceré časové a naratívne roviny 
a spomínanie prebieha $\mathrm{v}$ spleti vzájomne sa prekrývajúcich a prelínajúcich vrstiev. Pre detské ja rozprávačky Nelly využíva tretiu osobu (sie-formu), umožňujúcu rozprávačke $\mathrm{v}$ ich-forme $\mathrm{z}$ roviny prítomnosti nazerat na seba samu s odstupom, ako na niekoho cudzieho, ako na objekt. Uplatňuje však aj druhú osobu (du-formu) pre už dospelú postavu rozprávačky, ktorú sleduje na začiatku 70. rokov počas jej prvého návratu do rodného mesta v súčasnom Pol’sku, odkial v januári 1945 musela s rodinou utiect pred blížiacimi sa sovietskymi vojakmi.

Model detstva je hladaním spôsobu, ako v prítomnosti rozprávat o traumatických zážitkoch $\mathrm{z}$ minulosti a zároveň demonštrovat', ako $\mathrm{v}$ procese spomínania vstupuje súčasnost' a minulost', nevnímaná ako uzavretý úsek života, do vzájomných vztahov. $\mathrm{V}$ inscenovanom procese písania sa $\mathrm{v}$ Modeli detstva prelína tematika sebapísania $s$ reflexiami procesu spomínania. Proces nijako neurčuje chronológia minulých udalostí. Medzi spomienku a konkrétne rozprávanie spomienky sa s deklarovanou ambíciou emocionálnej zhody vsúva metanaratívna reflexia adekvátnej formy prezentácie spomienky v texte (Bareis - Grub 2010, 19). Rozprávačka na začiatku reflektuje aj zavrhnuté pokusy o literarizáciu minulej skúsenosti, v ktorých metaforizácia spomínania nadobúdala rôzne podoby - spomínanie ako račia chôdza alebo „ako pád do šachty času, na dne ktorej sedí dieta v celej svojej nevinnosti na kamennom schode a prvýkrát vo svojom živote v mysli povie samému sebe JA"12 (Wolf 1976, 11 - 12).

V Modeli detstva môžeme objavit aj interdiskurzívne prepojenia na diskurz zabúdania vo výskumoch pamäti. „Čo človek nevidel alebo takmer nevidel, sa dá lahšie zabudnút. Zabudnuté sa hromadilo“13 (419). Rozprávačka tak komentuje stret svojej rodiny na úteku so ženami v trestaneckom oblečení, od ktorých rýchlo odvrátili zrak. Zabúdanie je tu identifikované ako stratégia vytesnenia bolestných a zahanbujúcich skúseností z pamäti motivovaná snahou zachovat si pozitívny sebaobraz. Spomienky, ktoré spochybňovali morálnu integritu členov rodiny, sa v rodinnom spomínaní trvalo potláčali a tabuizovali. Ako pri charakteristike stratégií vytesnenia s odkazom na Freuda píše Aleida Assmann: „Na biele miesta sa nedá spomínat ${ }^{\text {“14 }}(2006,175)$. Predmetom spomínania sa nemôže stat to, čo sme v minulosti vedome nevnímali, pretože sme si to nechceli pripustit' (175). Zároveň možno túto i mnohé podobné situácie v Modeli detstva usúvztažnit’ s konceptom dialogického zabúdania, ktoré o desatročia neskôr predstavila Aleida Assmann ako prvý zo štyroch modelov zaobchádzania s traumatickou minulostou $(2013,182$ - 187), prevažujúci v medzinárodnej praxi počas prvých povojnových desatročí. Vdaka kolektívnemu zamlčiavaniu zdanlivo zabudnutých udalostí bola zátaž traumatickej minulosti najprv „anestézovaná“ (184), aby sa neotvárali staré rany, aby spomienky neudržiavali v mysliach deštruktívne sily, nepodnecovali vznik nových resentimentov a pomstu a aby bol možný zmier. Navyše, počas studenej vojny akoby bola pamät európskych národov zmrazená v prospech stabilizácie nových spojenectiev na oboch stranách Berlínskeho múru. Mlčalo sa pritom o vlastnom utrpení, ako aj o utrpení spôsobenom druhým (185). Cestu novej kultúre spomínania (u Aleidy Assmann ide o modely „spomínanie ako prekážka zabudnutia“ a "spomínanie ako vyrovnávanie sa s minulostou“) potom otvárali nielen filozofické diela (napríklad Hannah Arendt a jej Pôvod totalitarizmu, slov. 2018), ale aj literárne texty. 
Model detstva vyšiel v NDR v období, ked'skúsenost úteku nemeckého obyvatel'stva na sklonku vojny žila síce v rodinnej pamäti, ale v oficiálnej kultúre spomínania nebola vôbec prítomná. Koncom roka 1976 určovalo kultúrny život vyhostenie kritického pesničkára Wolfa Biermanna, ktoré verejne kritizovali prominentní východonemeckí umelci, medzi nimi aj Christa Wolf. Jej dielo však bolo už v polovici 70. rokov pod drobnohladom východonemeckých orgánov. Námietky cenzorov komunistického režimu $\mathrm{v}$ posudzovacom procese sa koncentrovali aj na stvárnenie tabuizovaných znásilnení ruskými vojakmi $\mathrm{v}$ texte autorky, prelamovanie tabu sexualizovaného násilia sa v literárnovednom diskurze čoraz častejšie spájalo so „ženským písaním“. V 17. kapitole, v „kapitole strachu“ (462) situovanej do augusta 1945, je téma násilných činov voči nemeckým ženám nakoniec prezentovaná so zjavnou opatrnostou v kombinácii reflexií vznikajúcich počas písania knihy, spomienok na rozhovory rozprávačky s ruskými priatelmi a relativizujúcich komentárov $\mathrm{k}$ mechanizmom vytesnenia traumatických skúseností. Autorka sa zásadne vyhýba zobrazeniu Rusov ako páchatelov, necháva svoju Nelly dokonca bojovat's pocitmi viny za násilie, ktorého sa vojaci dopúštali pri prepadoch osamelého gazdovského domu, rozprávačka miestami až banalizuje vlastnú skúsenost’ a jej spomienky nadobúdajú podobu rodinnej anekdoty. V NDR sa v tomto prípade miešali dlho tradované etické stereotypy s ideologickými a politickými dôvodmi tabuizovania historicky konkrétneho sexualizovaného násilia z roku 1945. Individuálne spomienky znásilnených žien sa uchovávali takmer výlučne v rodinnej ústnej komunikácii a téma sa až po roku 1989 postupne stala súčastou verejného diskurzu. Pritom je nezanedbatelné, že aj v diskurze západných spolkových krajín dominovala reflexia násilných činov príslušníkov Červenej armády, nie vojakov ostatných mocností. ${ }^{15}$

Ešte pred publikovaním knihy Model detstva sa v Akadémii umení NDR uskutočnili literárne čítania vybraných kapitol spojené s diskusiami, ktoré neskôr pokračovali v časopise Sinn und Form vydávanom akadémiou. Predstavitelia oficiálnej kultúrnej politiky si jasne uvedomovali popularitu autorky a jej moc ovplyvnit verejný diskurz. Diskusie, predovšetkým polemika literárnej kritičky Annemarie Auer (1977), však ukázali, k akému stretu s oficiálnym pamätovým diskurzom NDR, založenom výlučne na komunistickom odboji voči nacistickému režimu chápanému ako diktatúra finančného kapitálu, došlo v Modeli detstva pri problematizovaní procesov spomínania vychádzajúcom $\mathrm{z}$ individuálnej skúsenosti autorky. ${ }^{16}$ Annemarie Auer zverejnila ako reakciu na Model detstva tridsatstranový text s názvom Gegenerinnerung (Protispomienka), v ktorom autorke vyčíta, že namiesto zamerania na spolahlivý, osvedčený humanizmus je jej kniha elitársky zahladená do vlastného ja a rezignuje na historickú dialektiku. Politický postoj Christy Wolf považuje Auer za nejasný, želala by si zobrazenie vojny a povojnového obdobia z jednoznačnej antifašistickej perspektívy: „Určujúce prvky nášho eticko-kultúrneho dedičstva máme hladat v spomienkach účastníkov odboja. Tam sú uložené“17 $(1977,877)$. Práve autority komunistického odboja so skúsenostou obetí nacizmu určovali ako morálne vzory dlhodobo kolektívnu pamät v NDR. Antifašistické dedičstvo týchto martýrov bolo nespochybnitelné a v oficiálnom diskurze sa mu nemohli približit žiadne iné skupiny obetí, na ktoré sa zabúdalo, a tým aj na vlastný podiel zodpovednosti či 
viny. Dôležitý v reakciách na polemiku Annemarie Auer bol preto hlas spisovatela Stephana Hermlina, ktorý v Modeli detstva videl „signál ukončenia dlhého mlčania“ $(1977,1318)$.

\section{MESTO ANJELOV}

S Modelom detstva býva často porovnávaná posledná autobiografická kniha Christy Wolf Mesto anjelov z roku 2010, v ktorej sa pokúša skonštruovat zo siete spomienok na udalosti minulých desatročí vlastný „model života“. Velmi dlhé obdobie prúdila kreativita a do velkej miery aj životná sila Christy Wolf do náročného procesu sebaspytovania počas tvorby práve tejto knihy, ako potvrdzujú viaceré neskoré texty autorky, ale aj posmrtne vydané publikácie $(2013,25,128,149)$. Proces vzniku textu spojený s reflexiou spomínania je v oboch dielach výrazným štruktúrotvorným prvkom. V obidvoch textoch sa navyše sebaspytovanie spája s cestou rozprávačky, $\mathrm{v}$ Modeli detstva je to cesta do Polska, v Meste anjelov do Kalifornie.

V Meste anjelov prebieha spomínanie v spleti mozaikovitých narácií, samotná autorka používa metaforu tkaniva (Gansel - Wolf 2014, 354), z ktorého možno iba tažko vytiahnut jednu nit' bez toho, aby sa nezničil celok, podobne ako nemožno vynechat’ jednu líniu z „modelu života“. Kým v Modeli detstva metaforizuje Wolf spomínanie ako vrstvenie, jednotlivé vrstvy ležia pod sebou či nad sebou alebo vedla seba, teraz sa pokúša o siet', ktorou chce vyjadrit to, čo sa v reálnom živote deje pri spomínaní v zlomkoch sekúnd, ked' len jedno slovo vyvolá spomienku a s ňou nové asociácie, pričom prechody sa niekedy dejú uprostred jedného odseku či dokonca vety (354). V závere Modelu detstva sa pamät rozprávačke ešte javí ako úložisko anekdot, jeho štruktúra korešponduje so štruktúrou pointovaného príbehu, štruktúrou s jasnými reláciami. „Spracovanie zložitých úsekov dejín, v ktorých isté relácie ešte nie sú vyjasnené, v podobe anekdoty do novín, pri príležitosti výročí si vyžaduje „aplikovanie zmiešanej techniky: Zmazat', vybrat', vypointovat" ${ }^{\text {"18 }}$ (Wolf 1976, 464).

V Meste anjelov sa spomína na pobyt rozprávačky v Kalifornii v Los Angeles, meste anjelov, na začiatku 90. rokov a zároveň sa spomína na spomienky, ktoré sa počas amerického pobytu postupne vynárajú $\mathrm{z}$ hlbších vrstiev minulosti. Rozprávačka kombinuje každodenné zážitky, asociácie, správy z ciest, snové príbehy a inscenované pasáže $\mathrm{z}$ minulosti s fragmentmi spomienok.

$\mathrm{V}$ tkanive rozprávania sa strieda rozprávajúce ja (ich-forma) a minulé ty (du-forma), prelínajú sa časy. Roviny, v ktorých je udomácnené ja, sa kryjú so zážitkami zo štipendijného pobytu v USA v rokoch 1992 - 1993 a s časovou rovinou zahŕňajúcou roky nového tisícročia, približne roky 2000 - 2010, ked’ rozprávačka spracúva svoje spomienky do literárneho textu. Odstup od spomínaného vyjadruje druhá osoba jednotného, niekedy aj množného čísla (ihr). Do roviny prítomnosti zasahujú aj prevzaté poznámky rozprávačky zaznamenané $\mathrm{v}$ čase pobytu v Kalifornii. V texte sú typograficky odlíšené kapitálkami.

Rozprávačka Mesta anjelov sa spolieha na emocionálnu pamät: „EMOCIONÁLNA PAMÄŤ JE NAJTRVALEJŠIA A NAJSPOLAHLIVEJŠIA. PREČO JE TO TAK? POTREBUJEME JU ZVLÁŠŤ NALIEHAVO, ABY SME PREŽILI?"19 (Wolf 2010, 43). Rozhovory o nemecko-židovských emigrantoch a stretnutia s ich potomkami 
otvárajú priestor hlbokému trvalému smútku (102), ale iniciujú súčasne aj nové aspekty spomínania rozprávačky na vlastnú traumatickú skúsenost' úteku, na vytesnenú bolesṫ zo smrti starej mamy, ktorá počas úteku v roku 1945 zomrela od hladu. Rozprávačka priznáva, že v skutočnosti nikdy za ňou nesmútila, pretože si zakázala vnímat starú mamu ako nevinnú obet', vytesnila túto bolestnú skúsenost: „Odstrihla som svoje city, pretože som mala a chcela stratu vlasti a naše utrpenie pokladat za spravodlivý trest za nemecké zločiny. Bolest’ som si nepripustila" ${ }^{\text {"20 }}(405-406)$.

$\mathrm{V}$ procesoch metaforizácie pamäti sú tiež zjavné paralely s Modelom detstva. Metafora spomínania ako zostúpenia do šachty minulosti a postupného odkrývania vrstiev času $(205,270)$ je analógiou k metaforike pamäti charakterizovanej Aleidou Assmann (1999, 158 - 164), vytesnené zážitky je nutné „,vydolovat“", „vykopat“.

Mesto anjelov uvádzajú citáty signalizujúce snahu o pravdivost', prvý od Waltera Benjamina: „Pravdivé spomienky tak musia postupovat ani nie tak spravodajsky, ako skôr presne označit miesto, na ktorom k nim bádatel’ dospel ${ }^{\text {‘21 }}$ (Wolf 2010, 7). Druhý citát je od E. L. Doctorowa: „Skutočnú konzistenciu prežitého života nedokáže zobrazit žiadny spisovate ${ }^{\star 22}$ (9). V tkanive spomínania sú výrazné línie spomienok na život prežitý v rozporuplnej východonemeckej realite, ale aj na udalosti roku 1989, na prejav rozprávačky počas masovej demonštrácie v Berlíne 4 . novembra alebo na činnost' vo vyšetrovacej komisii, ktorá mala preskúmat zásah polície proti demonštrantom v noci zo 7. na 8. októbra v Berlíne. Text je zároveň svedectvom štrukturálneho násilia po zániku NDR.

Pri čítaní je evidentné, že v tkanive spomienok je jedna ústredná nit', ktorá vedie $\mathrm{k}$ vytesnenej téme, $\mathrm{k}$ opisu kontaktu s tým úradom, „ktorý bol zo všetkého zla stelesneného zanikajúcim štátom ten najzločinnejší, diabolský, ktorý infikoval každého, kto s ním prišiel do styku“23 $(178$ - 179). Už predtým sa v texte objavuje úvaha o monštruóznej a obludnej povahe človeka (141). Rozprávačke sa zdá, že z nej robia rovnaké monštrum: „V MESTE ANJELOV MA SŤAHUJÚ Z KOŽE. CHCÚ VEDIEŤ, ČO JE POD TYYM, A NACHÁDZAJÚ AKO U OBYČAJNÉHO ČLOVEKA SVALY ŠLACHY KOSTI ŽILY KRV SRDCE ŽALÚDOK PEČEŇ SLEZINU. SÚ SKLAMANÍ, DÚFALI, ŽE NÁJDU VNÚTORNOSTI MONŠTRA“24 (140 - 141).

Christa Wolf sa v máji 1992 dozvedela, že v úrade, ktorý spravuje spisy Ministerstva pre štátnu bezpečnost’ NDR (Stasi), evidujú takzvaný „spis páchatela“', ktorý dokumentuje, že v období rokov 1959 - 1962 sporadicky so Stasi spolupracovala. Až ked' bola v Kalifornii, priznala existenciu útleho fascikla, ktorý obsahuje niekolko, ako uvádzajú dokumenty, „zdržanlivých“ rozhovorov s pracovníkmi Stasi a jednu správu, ktorú Wolf napísala vlastnou rukou pred viac ako tridsiatimi rokmi (Vinke 1993, 22 - 24). Tajná služba sama kontakty s „nepoužitelnou“ spolupracovníčkou v roku 1962 ukončila a spis bol uzavretý.

Popri dvoch zväzkoch „spisu páchatela“ sa v archíve nachádza štyridsatdva zväzkov takzvaného „spisu obete“ dokumentujúcich intenzívne sledovanie Christy Wolf a jej manžela Gerharda z rokov 1968 - 1980. Predpokladá sa, že spisy z 80. rokov boli skartované.

Autorka tieto súvislosti prvýkrát zverejnila v januári 1993 v novinách Berliner Zeitung v texte s názvom „Eine Auskunft“ (Informácia; Vinke 1993, 143 - 144). V sep- 
tembri 1993 potom Hermann Vinke vydal pod názvom Akteneinsicht Christa Wolf: Zerrspiegel und Dialog (Nahliadnutie do spisu Christy Wolf: Krivé zrkadlo a dialóg) kompletnú dokumentáciu spisu a reakcií médií na informáciu o jeho existencii, ako aj výber korešpondencie autorky zo zložitého obdobia po zverejnení kontaktov, ktoré ešte výraznejšie polarizovalo nelútostný literárny spor trvajúci od roku 1990. Diskurzívne praktiky v spore spochybňovali morálnu integritu východonemeckých autoriek a autorov a mali zdiskreditovat aj ich literárne dielo. Ako v diferencovanej analýze literárneho sporu píše Helmut Peitsch $(1995,47)$, kritiku spoločenskej a politickej moci v NDR v spore nahradila kritika jej kritikov. Medzi nich patrila aj Christa Wolf, ešte tesne pred rokom 1989 v západnom Nemecku uctievaná spisovatel'ka a v NDR kultúrna ikona. Žurnalistický interdiskurz ju teraz stigmatizoval iba ako IM Margarete, neoficiálnu spolupracovníčku tajnej služby s krycím menom, a vôbec nerešpektoval autorkinu výraznú emancipáciu začínajúcu sa už v 60. rokoch. Tie dve písmená „ta nepripravenú zmietli do inej kategórie ludi' ${ }^{25}$ (Wolf 2010, 186), spomína rozprávačka v Meste anjelov.

Aleida Assmann $(1999,344)$ pripomína, že po zmene politických pomerov sa spolu s hodnotovým systémom vždy mení aj stav archívu. Zdôrazňuje, že žiadna politická moc sa nevzdá kontroly nad archívmi, a upozorňuje na mocenské štruktúry, ktoré sú v archíve ukotvené. Kontrola archívu je kontrolou pamäti. V prípade zväzkov Ministerstva pre štátnu bezpečnost' NDR nastal zriedkavý prípad, ked’ sa kompletný archív zaniknutého štátu dostal do správy iného štátu. Masívnym sprístupnením archívu sa Stasi stala najintenzívnejšie skúmanou inštitúciou bývalej NDR, verejné odhalenia spolupráce s tajnou službou sa pritom vo velkej miere koncentrovali práve na osobnosti z oblasti umenia.

Interdiskurzívne spomínanie v Meste anjelov metaforizuje tajnú službu ako diabolský úrad, opakovane sa však vracia k otázke, ako práve autorka, ktorá sa dlhé desatročia zaoberala procesmi spomínania, mohla na svoje stretnutia s tajnou službou zabudnút. Sledujeme postupné obnovovanie pamäti až po priznanie, že si rozprávačka nespomína na konanie svojho druhého ja. Autorka si tu nakoniec pomáha cudzím jazykom, ktorý metaforizuje ako ochranný štít a zároveň ako skrýšu. Pozoruje, o čo lahšie sa jej vyslovuje „I am ashamed“ v angličtine ako v materinskom jazyku, ale vie, že „anglické slovo ,pain' by [...] nikdy nemohlo vyjadrit' bolest', s ktorou som mala dočinenia ${ }^{\text {"26. }}$. Rovnako anglické výrazy pre svedomie a lútost' sú pre ňu nepoužitel'né $(217$ - 218).

Christa Wolf na tomto mieste znovu rozlišuje medzi spomínajúcim a zažívajúcim subjektom, dokonca uprostred vety používa ich-formu pre spomínajúce ja a druhú osobu, du-formu, pre rozprávačkino minulé ja, ktorého konanie kriticky reflektuje. Úmysel dištancovat sa od chýb minulosti je $\mathrm{v}$ tejto konštrukcii zrejmý. Ked' rozprávačka zostúpi do šachty minulosti, hladí tam na ňu cudzí človek (270). V sne nebezpečne prepadáva cez vrstvy času, ale ocitá sa nakoniec „,na pevnej pôde“ (320).

\section{ZÁVER}

Po zjednotení Nemecka sa práve oficiálne spomínanie na minulost' východného bloku, z ktorého boli životné skúsenosti obyvatelstva bývalej NDR do velkej miery vylúčené, stalo impulzom na výrazné individuálne spomínanie. Interdiskurzívne 
spomínanie v analyzovaných autobiografických literárnych textoch pôsobí ako komplementárny fenomén $k$ archívu s jeho snahou o homogenizáciu pamäti (Assmann 1999, 344), ale aj k často polarizovanému mimoliterárnemu, žurnalistickému diskurzu. Christu Wolf už od 60. rokov minulého storočia viedla snaha upriamit zložitý proces spomínania na vytvorenie komplexnejšieho obrazu minulosti, metafory a naratívne konštrukty v jej dielach neredukujú komplexnost' spomienok. Hoci si autorka uvedomuje nebezpečenstvo „preštruktúrovania“ literárneho textu, nemôžu sa podla nej štruktúry rozprávania kryt’ so štruktúrami prežívania a jednotlivé vlákna hustej spleti spomienok sa nedajú preložit do lineárneho jazyka. Viachlasné a relativizujúce písanie má napriek svojej nesúrodosti a vysokým nárokom kladeným na čitatela silnú spoločenskú dimenziu.

Lipský sociológ Thomas Ahbe metaforizuje východonemecké spomínanie ako ladovec: „Dobre viditel’né nad hladinou vody sa pohladu pozorovatela núkajú naratívy štátom privilegovanej pamäti diktatúry. Najväčšia čast východonemeckých spomienok sa však nachádza v tme, pod hladinou vody. Nevnímame ju, pretože jej naratívy sú ambivalentné a nielen doplňajú a diferencujú, ale aj dementujú naratívy pamäti

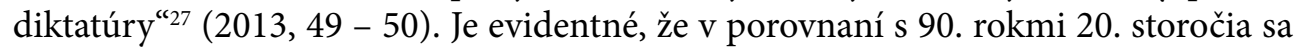
v novom tisícročí už vecnejšie narába s poznaním, že diskurz bývalého obyvatelstva NDR o vlastnej identite podlieha iným pravidlám ako oficiálny diskurz o nemeckej jednote a nemeckom rozdelení, ktoré jej predchádzalo (Goudin-Steinmann Hähnel-Mesnard 2013, 13).

Christa Wolf sa po roku 1989 stala terčom traumatizujúcich diskurzívnych praktík v mimoliterárnom priestore, dominantné naratívy verejného diskurzu, zväčša lineárne, pritom smerovali $\mathrm{k}$ „zjednoteniu“ pamäti. Čoraz diferencovanejšia recepcia textov autorky však ukazuje, že interdiskurzívne písanie môže spochybnit dominantné naratívy verejného diskurzu i oficiálne „nariadené“ stereotypné interpretácie minulosti, podnietit kritický odstup od hegemónneho diskurzu a komunikovat diferencované poznanie.

\section{POZNÁMKY}

1 Všetky pasáže citované z nemeckých zdrojov uvádzam vo vlastnom preklade.

2 Ide predovšetkým o teórie Jana Assmanna (1988), Aleidy Assmann (1999), Astrid Erll ([2005] 2011), Haralda Welzera $(2001 ; 2002)$.

3 „zu erzählen, das heißt: wahrheitsgetreu zu erfinden auf Grund eigener Erfahrung.“

4 "Sich-Erinnern ist gegen den Strom schwimmen, wie schreiben - gegen den scheinbar natürlichen Strom des Vergessens, anstrengende Bewegung."

5 Do slovenčiny román preložil Eduard V. Tvarožek. V štúdii používam názov románu zo slovenského prekladu, ale uvádzam vlastný preklad citovaných pasáží. Vhodnejší názov Vzory dětství bol zvolený v českom preklade Jaroslava Stř́teckého (1981).

${ }^{6}$ Prózu vydal manžel autorky Gerhard Wolf až tri roky po jej smrti.

"Nein, so ist es nicht gewesen."

8 „Das Vergangene ist nicht tot, es ist nicht einmal vergangen.“

9 „dessen Auftrag lautet: Vergessen! Verfälschen!“

10 „sondern eine Tätigkeit und die Voraussetzung, sie auszuüben, in einem Wort.“

${ }^{11}$ „Kreuzverhör mit dir selbst“ 
12 „als Fallen in einen Zeitschacht, auf dessen Grund das Kind in aller Unschuld auf einer Steinstufe sitzt und zum erstenmal in seinem Leben in Gedanken zu sich selbst ICH sagt."

${ }^{13}$ „Was man nicht oder fast nicht gesehen hat, kann man leichter vergessen. Der Vorrat am Vergessenen wuchs."

14 "An blinde Flecken kann man sich nicht erinnern.“

${ }^{15}$ K diskurzu pred rokom 1989 a po zjednotení Nemecka pozri bližšie Dahlke 1998, 39 - 44, a tiež Dahlke 2000.

${ }^{16}$ Pozri bližšie Priwitzer 2009, 53 - 59.

17 „Die bestimmenden Elemente unserer ethisch-kulturellen Überlieferung haben wir in den Erinnerungen der Widerstandskämpfer zu suchen. Dort sind sie niedergelegt."

18 „Die Verarbeitung schwieriger Geschichtsabschnitte, in denen gewisse Relationen noch ungeklärt sind, zu Zeitungsanekdoten, aus Anlaß von Jahrestagen [...] Anwendung der Mischtechnik: Löschen, auswählen, pointieren."

19 „DAS GEFÜHLSGEDÄCHTNIS IST DAS DAUERHAFTESTE UND ZUVERLÄSSIGSTE. WARUM IST DAS SO? WIRD ES BESONDERS DRINGLICH GEBRAUCHT ZUM ÜBERLEBEN?“

${ }^{20}$ „Ich habe meine Gefühle abgeschnitten, weil ich den Verlust der Heimat und unsere Leiden als gerechte Strafe für die deutschen Verbrechen empfinden sollte und wollte. Ich habe mich auf den Schmerz nicht eingelassen."

21 „So müssen wahrhafte Erinnerungen viel weniger berichtend verfahren als genau den Ort bezeichnen, an dem der Forscher ihrer habhaft wurde." Michael Haase toto motto interpretuje ako nutnost' "precízneho priestorového a časového určenia“ horizontu chápania, teda ako nutnost̉ rezignovat na snahu „vyzerat pre hanbu či márnomysel’nost múdrejší voči včerajšku“ $(2014,228)$.

22 „Die wirkliche Konsistenz von gelebtem Leben kann kein Schriftsteller wiedergeben.“

${ }^{23}$ „die von allem Bösen, das der untergehende Staat verkörperte, das Böseste war, das Teuflische, das jeden, der mit ihm in Berührung gekommen war, infiziert hatte."

24 „IN DER STADT DER ENGEL WIRD MIR DIE HAUT ABGEZOGEN. SIE WOLLEN WISSEN, WAS DARUNTER IST, UND FINDEN WIE BEI EINEM GEWÖHNLICHEN MENSCHEN MUSKELN SEHNEN KNOCHEN ADERN BLUT HERZ MAGEN LEBER MILZ. SIE SIND ENTTÄUSCHT, SIE HATTEN AUF DIE INNEREIEN EINES MONSTERS GEHOFFT.“

25 "schleuderten dich unvorbereitet in eine andere Kategorie von Menschen."

26 „das englische Wort ,pain für mich niemals den Schmerz bezeichnen könnte, mit dem ich es zu tun hatte“

27 „Gut sichtbar, über der Wasseroberfläche, bieten sich dem Blick des Betrachters die Narrative des staatlich privilegierten Diktaturgedächtnisses. Der größte Teil der ostdeutschen Erinnerung aber befindet sich im Dunkel, unter der Wasseroberfläche. Er wird nicht wahrgenommen, weil seine Narrative ambivalent sind und weil sie die Narrative des Diktaturgedächtnisses nicht nur ergänzen und differenzieren, sondern auch dementieren."

\section{LITERATÚRA}

Ahbe, Thomas. 2013. „Die ostdeutsche Erinnerung als Eisberg: Soziologische und diskursanalytische Befunde nach 20 Jahren staatlicher Einheit." In Ostdeutsche Erinnerungsdiskurse nach 1989: Narrative kultureller Identität, eds. Elisa Goudin-Steinmann - Carola Hähnel-Mesnard, 27 - 58. Berlin: Frank \& Timme.

Assmann, Aleida. 1999. Erinnerungsräume: Formen und Wandlungen des kulturellen Gedächtnisses. München: Verlag C. H. Beck.

Assmann, Aleida. 2006. Der lange Schatten der Vergangenheit: Erinnerungskultur und Geschichtspolitik. München: Verlag C. H. Beck.

Assmann, Aleida. 2013. Das neue Unbehagen an der Erinnerungskultur: Eine Intervention. München: Verlag C. H. Beck.

Assmann, Jan. 1988. „Kollektives Gedächtnis und kulturelle Identität.“ In Kultur und Gedächtnis, eds. Jan Assmann - Tonio Hölscher, 9 - 19. Frankfurt am Main: Suhrkamp. 
Auer, Annemarie. 1977. „Gegenerinnerung.“ Sinn und Form 29, 4: 847 - 878.

Bareis, J. Alexander - Frank Thomas Grub, eds. 2010. Metafiktion: Analysen zur deutschsprachigen Gegenwartsliteratur. Berlin: Kadmos.

Benjamin, Walter. [1942] 1977. „Über den Begriff der Geschichte.“ In Illuminationen. Ausgewählte Schriften 1, ed. Siegfried Unseld, 251 - 261. Frankfurt am Main: Suhrkamp.

Dahlke, Birgit. 1998. „BeFreier und Befreite? Ein Symboldelikt im deutsch-deutschen Diskurs vor und nach 1989.“ GDR Bulletin 25, 1: 39 - 44. DOI: https://doi.org/10.4148/gdrb.v25i0.1247.

Dahlke, Birgit. 2000. „Tagebuch des Überlebens. Vergewaltigungen 1945 in ost- und westdeutschen Autobiographien. "In Autobiography by Women in German, eds. Meredid Puw Davies - Beth Linklater - Gisela Shaw, 195 - 212. Oxford u. a.: Peter Lang.

Erll, Astrid. [2005] 2011. Kollektives Gedächtnis und Erinnerungskulturen. Eine Einführung. 2. aktualizované a rozšírené vydanie. Stuttgart - Weimar: Metzler.

Gansel, Carsten - Christa Wolf. 2014. „,Zum Schreiben haben mich Konflikte getrieben ${ }^{\prime}$ - ein Gespräch. “ In Christa Wolf - Im Strom der Erinnerung, ed. Carsten Gansel, 353 - 366. Göttingen: V\&R unipress.

Goudin-Steinmann, Elisa - Carola Hähnel-Mesnard, eds. 2013. Ostdeutsche Erinnerungsdiskurse nach 1989: Narrative kultureller Identität. Berlin: Frank \& Timme.

Haase, Michael. 2014. „Christa Wolfs letzter ,Selbstversuch - Zum Konzept der subjektiven Authentizität in ,Stadt der Engel oder The Overcoat of Dr. Freud““. In Christa Wolf - Im Strom der Erinnerung, ed. Carsten Gansel, 215 - 230. Göttingen: V\&R unipress.

Halbwachs, Maurice. 1967. Das kollektive Gedächtnis. Stuttgart: Enke.

Hermlin, Stephan. 1977. „Brief zu Annemarie Auer.“ Sinn und Form 31, 6: 1318 - 1320.

Link, Jürgen. 1988. „Literaturanalyse als Interdiskursanalyse: Am Beispiel des Ursprungs literarischer Symbolik in der Kollektivsymbolik." In Diskurstheorien und Literaturwissenschaft, eds. Jürgen Fohrmann - Harro Müller, 284 - 307. Frankfurt am Main: Suhrkamp.

Link, Jürgen. 2013. „Diskurs, Interdiskurs, Kollektivsymbolik.“ Zeitschrift für Diskursforschung, 1: 7 - 23.

Nora, Pierre. 2002. „Gedächtniskonjunktur.“ Prel. Grete Osterwald. Transit: Europäische Revue 22: 18 - 31.

Peitsch, Helmut. 1995. „Vereinigung. Literarische Debatten über die Funktion der Intellektuellen.“ In Germany in the 1990s, ed. Hans J. Hahn, 39 - 65. Amsterdam - Atlanta, GA: Editions Rodopi.

Priwitzer, Jens. 2009. „Die Gegenwart der Geschichte - Zur Erinnerung an NS-Vergangenheit, Generationenerfahrung und ästhetische Innovationen bei Franz Fühmann, Christa Wolf und Günter Kunert." In Rhetorik der Erinnerung - Literatur und Gedächtnis in den "geschlossenen Gesellschaften" des Real-Sozialismus, ed. Carsten Gansel, 53 - 81. Göttingen: V\&R unipress.

Schmidt, Siegfried J. 1991. „Gedächtnisforschungen: Positionen, Probleme, Perspektiven.“ In Gedächtnis. Probleme und Perspektiven der interdisziplinären Gedächtnisforschung, ed. Siegfried J. Schmidt, 9 - 55. Frankfurt am Main: Suhrkamp.

Schubert, Katja. 2013. „,Are you sure this country does exist?` Blickwechsel als narrative Strategie im Werk von Christa Wolf." In Ostdeutsche Erinnerungsdiskurse nach 1989. Narrative kultureller Identität, eds. Elisa Goudin-Steinmann - Carola Hähnel-Mesnard, 285 - 302. Berlin: Frank \& Timme.

Vinke, Hermann, ed. 1993. Akteneinsicht Christa Wolf: Zerrspiegel und Dialog. Hamburg: Luchterhand Literaturverlag.

Welzer, Harald, ed. 2001. Das soziale Gedächtnis: Geschichte, Erinnerung, Tradierung. Hamburg: Hamburger Edition.

Welzer, Harald. 2002. Das kommunikative Gedächtnis: Eine Theorie der Erinnerung. München: Beck.

Wolf, Christa. 1976. Kindheitsmuster. Berlin und Weimar: Aufbau-Verlag.

Wolf, Christa. 1986. „Lesen und Schreiben.“ In Die Dimension des Autors. Band II, Christa Wolf, 7 - 47. Berlin und Weimar: Aufbau-Verlag.

Wolf, Christa. 1989. „Blickwechsel.“ In Gesammelte Erzählungen, Christa Wolf, 5 - 25. Berlin - Weimar: Aufbau-Verlag.

Wolf, Christa. 1990. Was bleibt. Berlin - Weimar: Aufbau-Verlag.

Wolf, Christa. 1994. Auf dem Weg nach Tabou. Texte 1990-1994. Köln: Kiepenheuer \& Witsch.

Wolf, Christa. 2003. Ein Tag im Jahr: 1960-2000. München: Luchterhand. 
Wolf, Christa. 2010. Stadt der Engel oder The Overcoat of Dr. Freud. Berlin: Suhrkamp.

Wolf, Christa. 2012. Rede, daß ich dich sehe: Essays, Reden, Gespräche. Berlin: Suhrkamp.

Wolf, Christa. 2013. Ein Tag im Jahr im neuen Jahrhundert: 2001-2011. Berlin: Suhrkamp.

Wolf, Christa. 2014. Nachruf auf Lebende: Die Flucht. Berlin: Suhrkamp.

Wolf, Christa. 2016. „Man steht sehr bequem zwischen allen Fronten“: Briefe 1952-2011. Ed. Sabine Wolf,

Berlin: Suhrkamp.

\title{
The interdiscursivity of remembrance in the literary work of Christa Wolf
}

Memory. Remembrance. Interdiscourse. Metaphor. Christa Wolf.

This article draws attention to the specific way in which the important German author Christa Wolf turns scientific findings on memory into literary material in her work. Remembrance and the associated self-exploration and self-knowledge form the core of what Christa Wolf calls subjective authenticity. Her key self-reflexive texts stage the process of writing, in which self-questioning intermingles with reflections on the process of remembrance and the literalization of the phenomenon of memory. In the 1990s, the author became the target of traumatic discourse practices in the non-literary space. The article also addresses the question of how interdiscursive remembrance contrasts with stereotypical interpretations of the past and what its potential to stimulate a critical distance from hegemonic discourse and the communication of differentiated knowledge may be.

\author{
PhDr. Nadežda Zemaníková, PhD. \\ Katedra germanistiky \\ Filozofická fakulta \\ Univerzita Mateja Bela v Banskej Bystrici \\ Tajovského 40 \\ 97401 Banská Bystrica \\ nadezda.zemanikova@umb.sk \\ ORCID: https://orcid.org/0000-0001-6584-7390
}

